\title{
Extraction of Maximum Power from Photovoltaic Array under Partial Shading Conditions
}

\author{
http://dx.doi.org/10.3991/ijes.v2i2.3660 \\ Aswathy Kanth \\ SNS college of Engineering, Coimbatore, India
}

\begin{abstract}
The efficiency of a photovoltaic(PV) array is greatly influenced by shading conditions. The PV arrays get shadowed, completely or partially, by the passing clouds, neighboring buildings and towers, trees, and utility and telephone poles. Under partially shaded conditions, the PV exhibits non convex characteristics with multiple peaks. Extraction of maximum power from $P V$ array is possible using bypass diodes or sub-module integrated converters (subMIC).This paper presents a comparative study of photovoltaic module with bypass diode and that with subMIC. A 3-module PV series string with bypass diode and with subMIC were simulated under mismatched solar irradiation conditions using MATLAB Simulink.
\end{abstract}

Index terms-PV arrays, partial shading, bypass diodes, sub-module integrated converters.

\section{INTRODUCTION}

Generally solar panels are divided into number of substrings and are connected in series. And in most PV systems, the presence of shade or mismatch have a greater impact on the system's power output. This is due to the serial nature of PV modules in strings, which creates a "Christmas tree effect" in which current reduction in one series-connected module causes mismatch losses in the rest of the string.

Under partial shading conditions, the entire generating capacity of all the good cells is dissipated in the poor cell. The enormous power dissipation occurring in a small area results in local overheating, or "hot-spots", which in turn leads to destructive effects, such as cell or glass cracking, melting of solder or degradation of the solar cell. In order to avoid hot spots in solar panels use of bypass diode or subMIC is adequate. The bypass diode allows current from non-shaded parts of the module to pass by the shaded part, and limits the effect of shading to only the neighboring group of cells protected by the same bypass diode [3].

Sub-module-integrated dc-dc converters (subMICs) can be configured to process only a mismatch fraction of power, present no insertion losses. The objective of minimum power processed by subMICs can be solved as a linear programming problem, and achieved using bidirectional subMICs and a central controller. A much simpler, close-to-optimal distributed control approach is possible that allows autonomous subMIC control without the need for a central controller or any communication of control or sensing signals among the subMICs [1].

This paper is organized in to four parts as (i) The photovoltaic module models under partial shading conditions (ii) effect of partial shading on photovoltaic module (iii) Photovoltaic module under partial shading condition with bypass diode(iv) photovoltaic module under partial shading conditions with subMIC

\section{The Photovoltaic Module Models Under PARTIAL SHADING CONDITIONS}

Many models of varying complexity describing the behavior of a PV cell are available. The simplest model is insufficient in most application, therefore a more complex model is needed if it is going to be able to deal with realities such as the shading problem. In this paper photo voltaic module is modeled in MATLAB according to the equations,

$$
I=I_{L G}-I_{0}\left\{\exp \left[\frac{q}{A K T}\left(V+I_{A} R_{S}\right)\right]-1\right\}
$$

where

$$
\begin{aligned}
& I_{0}=I_{o r}\left[\frac{T}{T_{r}}\right]^{3} \exp \left[\frac{q E_{G 0}}{B K}\left\{\frac{1}{T_{r}}-\frac{1}{T}\right\}\right] \\
& I_{L G}=\left[I_{S C R}+K_{1}\left(T_{C}-28\right)\right] \lambda / 100 .
\end{aligned}
$$

Where I is cell output current, $\mathrm{V}$ is cell output voltage, Io is cell saturation current $\mathrm{T}$ is cell temperature in $\mathrm{K}, \mathrm{K} / \mathrm{q}$ is Boltzmann's constant divided by electronic charge $8.62 * 10^{\wedge}-5 \mathrm{eV} / \mathrm{K}$, Tc is cell temperature in degree Celsius, $\mathrm{Ki}$ is short circuit current temperature coefficient at Iscr $0.0017 \mathrm{~A} /$ degreeCelsius,lamda is Cell irradiance $\left(\mathrm{mW} / \mathrm{cm}^{\wedge} 2\right)$, Iscr is cell short circuit current at 28 degree Celsius and $100 \mathrm{~mW} / \mathrm{cm} 2=4.57 \mathrm{~A}$, Ilg is light generated current,Ego is band gap for silicon $=1.11 \mathrm{eV}, \mathrm{B}=\mathrm{A}$ ideality factors $=1.92, \operatorname{Tr}$ is reference temperature $=301.18 \mathrm{~K}$, Ior is saturation current at $\operatorname{Tr}=19.963^{*} 10^{\wedge} 6$, Rs is series resistance $=0.001 \mathrm{ohms}$.

For light generated current Simulink is as shown in Figure 1.

Similarly modeling of both cell saturation current and output current according to the equations is possible. After converting it to subsystem, the entire PV panel can be obtained as in Figure 2.

In Figure 2 the PV panel is designed under normal condition. Similarly designing of solar panel under partial shading conditions by varying the irradiance value on the panel is also possible.

\section{EFFect of Partial Shading ON Photovoltaic MODULE}

We can think of a string of panels as something like a piece of pipe, and the solar power is like water flowing 


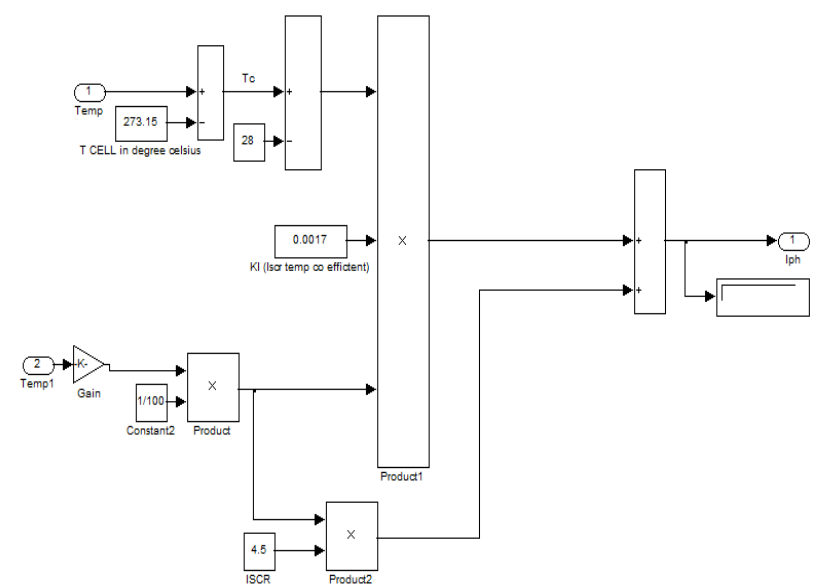

Figure 1. MATLAB modeling of light generated current

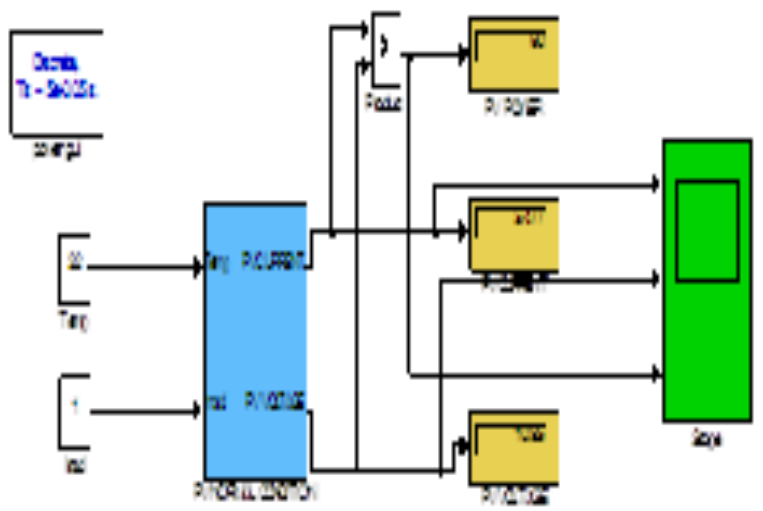

Figure 2. PV panel model in MATLAB

through that pipe. In conventional solar panel strings, shade is something that blocks that flow. If, for example, shade from a tree or a chimney is cast on even one of the panels in the string, the output of the entire string will be reduced to virtually zero for as long as the shadow sits there. If there is a separate, unshaded string, however, this string will continue to produce power as per usual.

Diagram below (Figure 3) shows the power output and voltage output from a solar panel under various irradiance conditions.

Mismatch conditions can occur due to the nonhomogeneous external characteristics of the cells, due to dissymmetric manufacturing, the degradation of the cell blooming layer, the manufacturing defects, the possible breaking of the cells, the dirt on the anterior part of the cells, the degradation of the materials used for the cells encapsulating and the unequally radiation of the cells. All these factors lead to a reduction of the module performances implying that the generated power of a module is less than the sum of the generated power of the single cells.

Figure 4 shows the simulation diagram of solar panel under partial shading conditions.

Here three PV modules are connected in series among which two of them produce sixty watts which are assumed to be non-shaded modules. And the third module is producing a power output of thirty watts only since it is assumed as a shaded module. Simulation of the arrangement

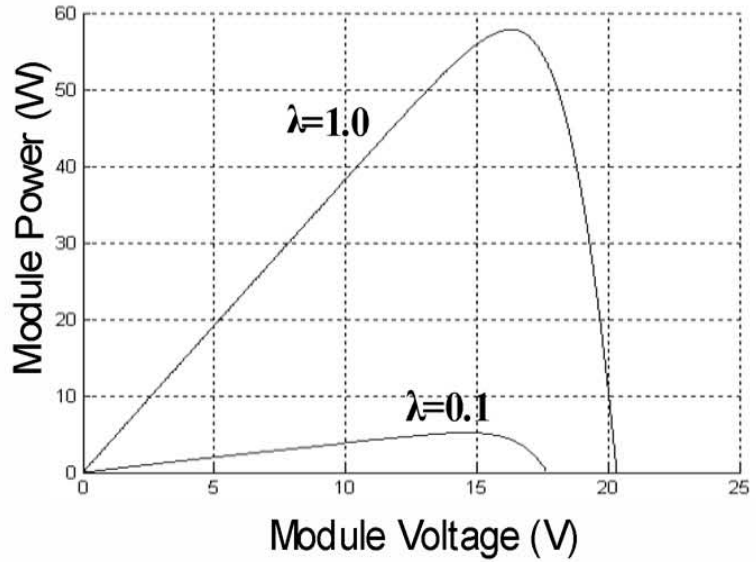

Figure 3. Module power verses module voltage graph

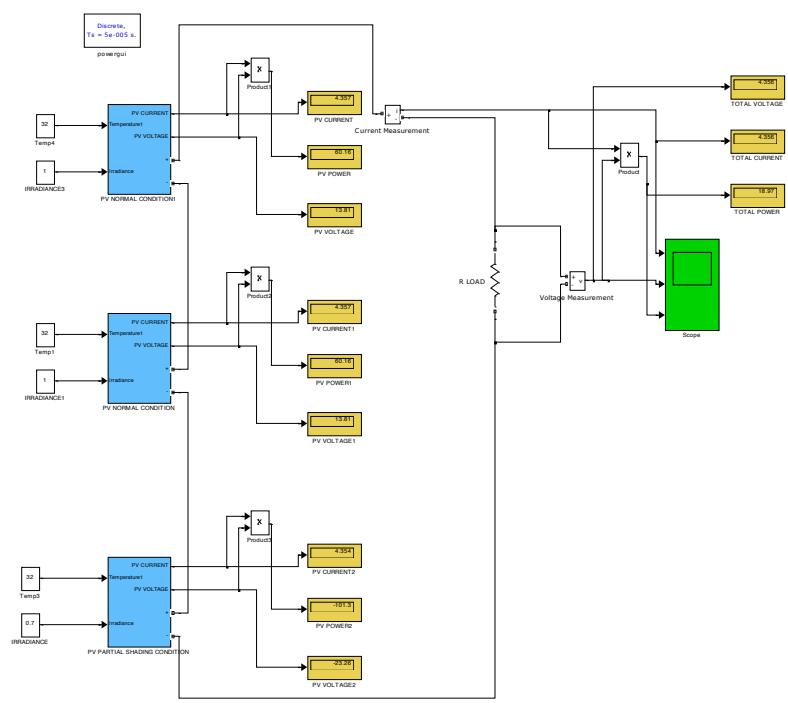

Figure 4. Simulation diagram of solar panel under partial shading conditions

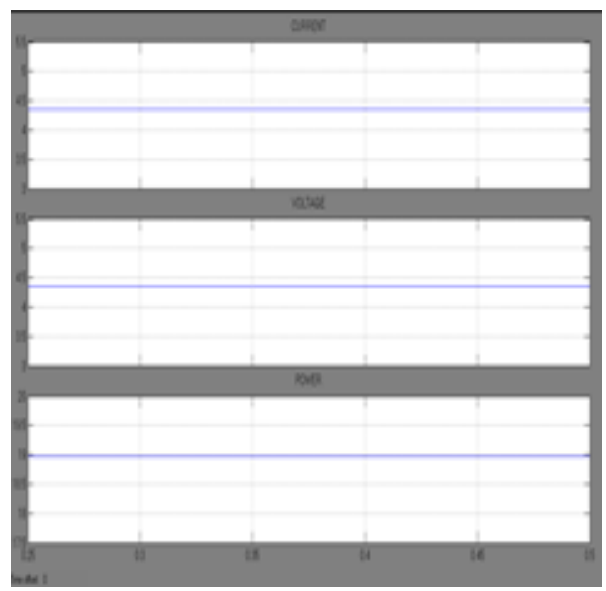

Figure 5. Simulated output of solar panel under partial shading conditions

shown in the figure above produces a power of about $15 \mathrm{~W}$ only. From simulated output, it is inferred that under partial shading conditions the maximum extraction of power from solar panel is not possible. Even if two PV modules are producing an output of sixty watts each it is unable to use that under partial shading conditions. Figure 5 shows the simulation output. 


\section{Photovoltaic Module Under Partial SHADING CONDITION WITH BYPASS DIODE}

The effect of partial shading on solar panel can be minimized using bypass diodes which minimize the effects of partial shading by essentially enabling electricity to 'flow around' the shaded cell and using subMIC.

Typically, a crystalline silicon module will contain bypass diodes to prevent damage from reverse bias on partially shaded cells. These diodes are placed across 12-18 cells in what will be termed a 'group' of cells here. The bypass diode across this group of cells will begin conducting before the power dissipated into the shaded cell is enough to evolve damaging temperatures.

The bypass diode allows current from non-shaded parts of the module to pass by the shaded part, and limits the effect of shading to only the neighboring group of cells protected by the same bypass diode. When a bypass diode begins conducting, the module voltage will drop by an amount corresponding to the sum of cell voltages protected by the bypass diode plus the diode forward voltage, but current from surrounding unshaded groups of cells continues around the group of shaded cells.

Under normal operation, each solar cell will be forward biased and therefore the bypass diode will be reverse biased and will effectively be an open circuit. However, if a solar cell is reverse biased due to a mismatch in shortcircuit current between several series connected cells, then the bypass diode conducts, thereby allowing the current from the good solar cells to flow in the external circuit rather than forward biasing each good cell. The maximum reverse bias across the poor cell is reduced to about a single diode drop, thus limiting the current and preventing hot-spot heating. By-pass diodes will not be of use unless panels are connected in series to produce a higher voltage. They are most likely to be of benefit where an MPPT Controller or String Inverter involves panels connected in series to produce voltages well above that items minimum input voltage.

When bypass diode are connected across PV module, multiple peaks in voltage-power characteristics are observed. Figure 9 shows the non-convex characteristics caused by the use of solar panel with bypass diode. Classical MPPT methods are not effective due to their inability to discriminate between local and global maximum. Global MPPT algorithm may be used to track the global maximum power point of PV array under partial shaded conditions.

The simulation diagram of solar panel with bypass diode is similar that of figure 5 except the addition of bypass diode in it. Even though the arrangement is supposed to give a power output of $150 \mathrm{~W}(60+60+30)$, it is giving an output of $120 \mathrm{~W}(60+60)$ only (but which is better than output given by solar panel without bypass diode).

\section{Photovoltaic Module Under Partial SHADING WITH SUBMIC}

In order to extract maximum amount of power from a PV module under partial shading conditions, use of submodule integrated converters is very necessary.

Basic working principle of a subMIC is "Voltage or Power equalization". In VEP, voltage across each substring is made equal, or power delivered by each substring is made equal. This is possible by the injection or extraction of current in PV module by the operation of subMIC.

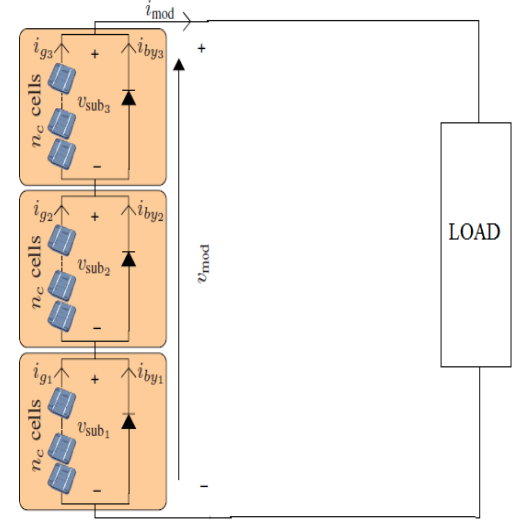

Figure 6. Schematic diagram of PV module with bypass diode

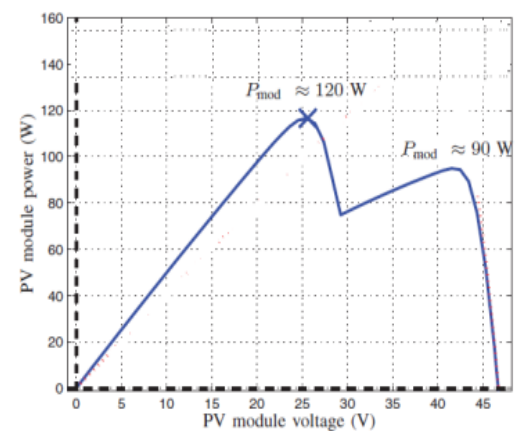

Figure 7. Non convex characteristics

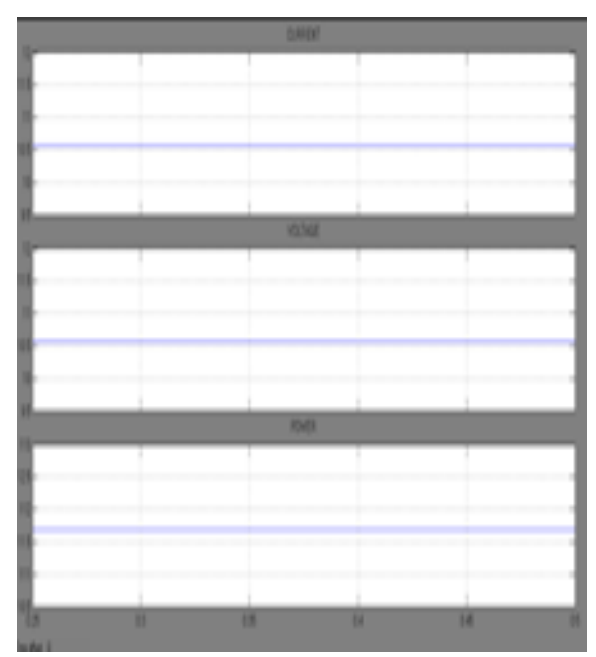

Figure 8. Simulation result for solar panel with bypass diode under partial shading conditions

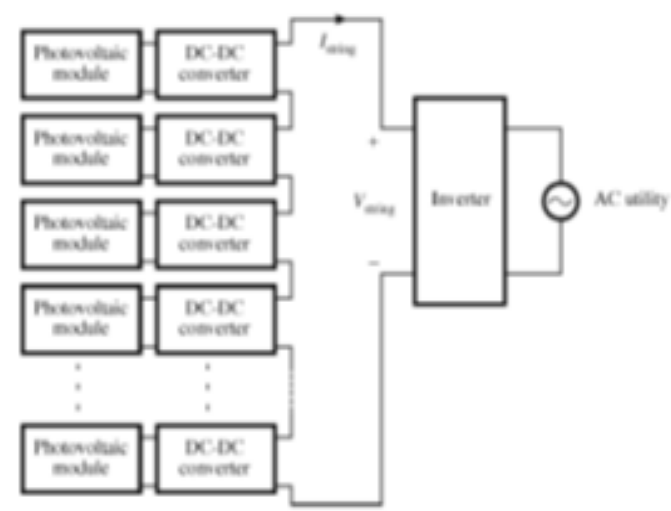

Figure 9. Block diagram of subMIC enhanced PV module 
PAPER

EXTRACTION OF MAXIMUM POWER FROM PHOTOVOLTAIC ARRAY UNDER PARTIAL SHADING CONDITIONS

A sub-module integrated converter (subMIC) is nothing but a bidirectional dc-dc converter use of which in parallel with each PV module gives maximum extraction of power. Dc-dc converter topology used here is a bidirectional flyback converter. The Output of each flyback converter is connected in parallel and are isolated from the solar module. Isolated topology permits the independent choice of rating of parameters on the secondary of the converter. The operation of solar panel under partial shading condition with subMIC is explained with help of diagram shown in figure 10.

The subMIC connected across the PV module which is under partial shading condition is handling a power of $20 \mathrm{~W}$. This $-20 \mathrm{~W}$ is extracted from the solar module under normal condition (10W each). Thus a total power output of $150 \mathrm{~W}(50+50+50)$ is obtained. Unlike the use of bypass diode, subMIC gives convex characteristics. That is, the use of subMIC in solar panel gives only one peak in voltage power characteristics. Therefore the use of MPPT in sub-module integrated converter is very easy.

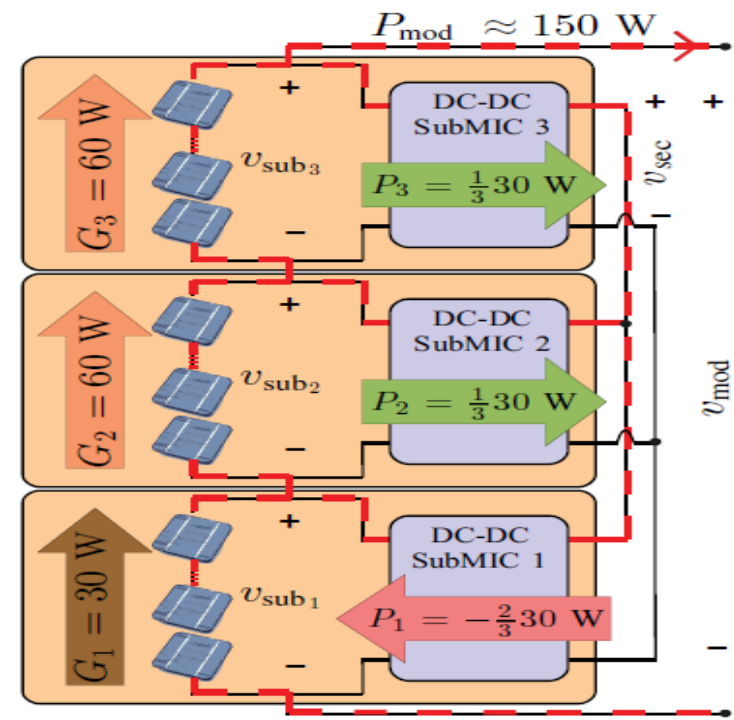

Figure 10. operation of solar panel with subMIC under partial shading conditions

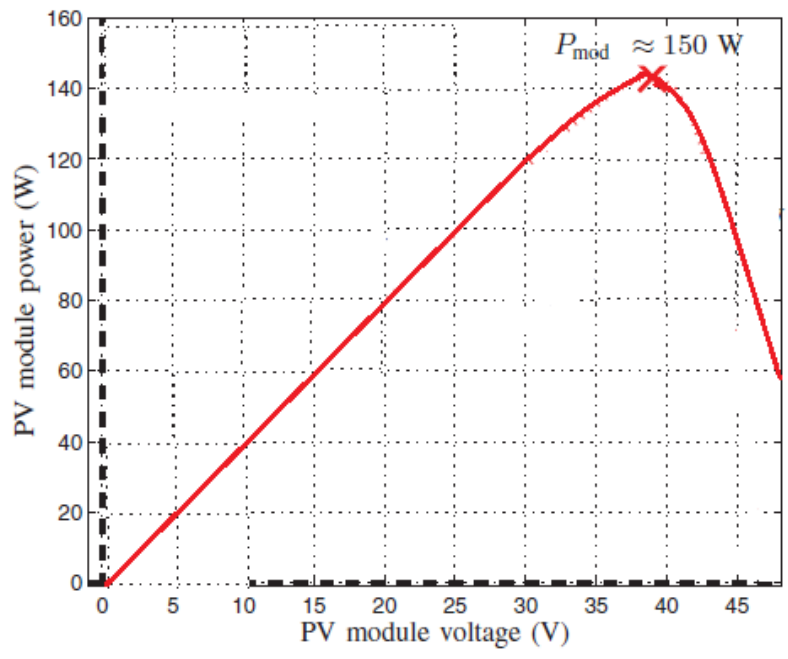

Figure 11. Convex characteristics

\section{A. Converter topology-bidirectional flyback converter}

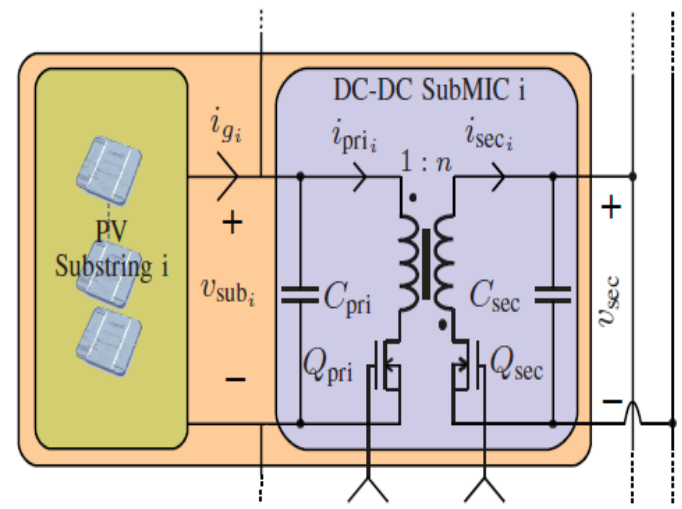

Figure 12. Bidirectional flyback dc-dc converter

The dc-de converter topology uses two MOSFET switches for bidirectional power flow. It can operate in two different modes. During mode- 1 the duty cycle of switch-1 is set greater than duty cycle of switch-2 and voltage across the PV module is greater than converter voltage. Therefore the power flows from PV Module to converter output.

During mode-2 the duty cycle of switch-2 is set greater than duty cycle of switch-1 and voltage across the PV module become less than (under partial shading condition) converter voltage. Therefore the power flows from PV Module to converter output. The converter topology uses a special controller which is a sensor less current controller.

\section{B. Controller Design in MATlab}

For the control of bidirectional power flow a controller (sensor less current controller) is designed in MATLAB. The gating pulses to two MOSFET in bidirectional flyback converter is provided by this controller.

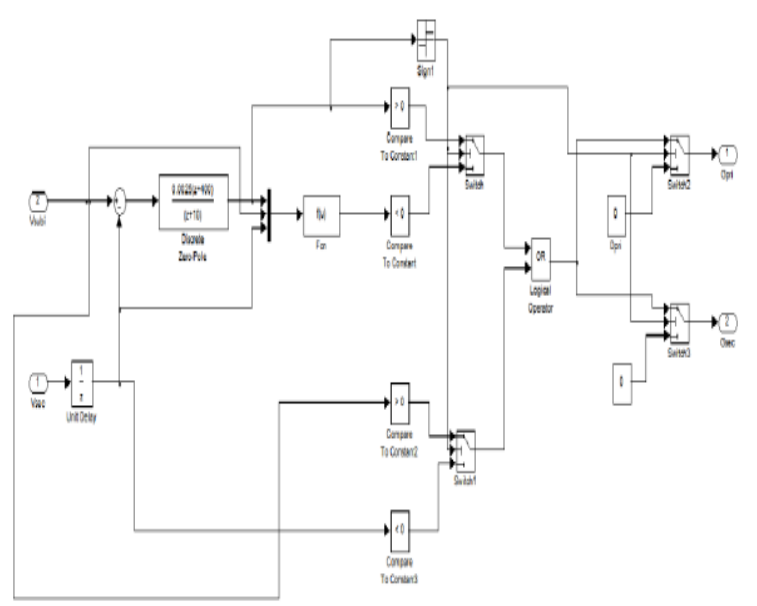

Figure 13. Model of sensor less current cont- roller in MATLAB

The controller compares two voltages (voltage across the subMIC and PV module voltage). Then the difference is multiplied with a transfer function to convert the secondary value to primary value. After the comparison (taking account of sign of output) two gate pulses are produced. 


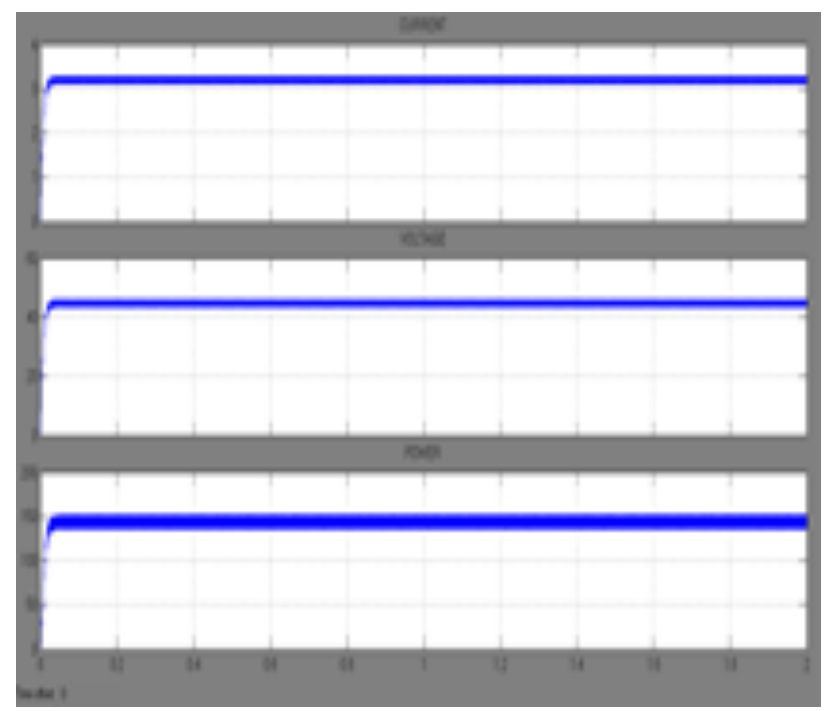

Figure 14. Simulation result for solar panel with subMIC under partial shading condition

Simulation result shows that, the use of subMIC in solar panel under partial shading conditions gives extraction of maximum amount of power $(60+60+30=150 \mathrm{~W})$.

\section{CONCLUSION}

The use of bypass diode and sub-module integrated converter with solar panel gives a ray of hope for the efficient utilization of solar energy under partial shading conditions. Use of bypass diode gives an efficiency about $80 \%$ while the use subMIC provides an efficiency of about $90 \%$. These results opens scenarios of conceivable modifications to the PV field configurations today chosen under partial shading conditions.

\section{REFERENCES}

[1] H. P Forghani-zadehand G. A. Rincón-Mora"Current-Sensing Techniques for DC-DC Converters" IEEE transactions on power electronics, vol. 28, no. 4, april 2013

[2] L.Huang, P. Thummala, Zhe Zhang and M.Andersen "Battery Powered High Output Voltage Bidirectional Flyback Converter for Cylindrical DEAP Actuator"'

[3] C.Olalla,D.Clement,M.Rodriguezand.D.Maksimovic“Architecture $\mathrm{s}$ and Control of Sub-module Integrated DC-DC Converters for PhotovoltaicApplications"IEEE transactions on power electronics, vol. 28, no.6,june2013 http://dx.doi.org/10.1109/TPEL. 2012.2219073

\section{AUTHOR}

Aswathy Kanth is PG scholar, Department of EEE, SNS college of Engineering, Coimbatore, Pin:-641 107, Email ID:aswathykanth1@gmail.com.

Submitted 17 March 2014. Published as re-submitted by the author 12 May 2014. 